\title{
Artrodese subtalar do pé pelo método de llizarov*
}

\author{
Artrodese subtalar of the foot for the llizarov* method
}

\begin{abstract}
José Carlos Bonglovann I ; Hilário Boatto ${ }^{2}$; Emillo Palazzo Neto ${ }^{3}$; Carlos luis Engelen ${ }^{4}$; Antonio Augusto Couto de Magalhães ${ }^{5}$; PaUlo Roberto Mussi ${ }^{6}$
\end{abstract}

\section{RESUMO}

Foram tratados 28 pacientes num total de 29 pés, com idade média de 25,8 , predomínio do sexo masculino 16 pacientes $(57,2 \%)$, cor branca 25 pacientes $(89,2 \%)$, lado direito 16 pacientes $(57,2 \%)$. Quanto à etiologia houve um predomínio das seqüelas de fraturas de calcâneo 11 pacientes $(37,9 \%)$ e poliomielite 11 pacientes $(37,9 \%)$, as outras causas foram necrose do talus 2 pacientes $(6,9 \%)$, barra óssea 2 pacientes $(6,9 \%)$, artrose primária 2 pacientes $(6,9 \%)$ e paralisia cerabral 1 paciente (3,5\%). O tempo médio de consolidação foi de 3,5 meses. Foram utilizados enxerto ósseo em 11 pacientes (44\%). Houve necessidade em 2 casos $(6,9 \%)$ de se promover o alongamento do calcâneo para se aumentar o pitch do mesmo. A montagem é simples e se baseia em 2 anéis com fixação transóssea através de 2 fios olivados no talus e 2 no calcâneo. Como resultado foi obtido $100 \%$ de consolidação, ausência de dor e osteoporose e boa sensibilidade do pé. Das complicações encontradas além das costumeiras ou próprias do método 1 (3,5\%) paciente apresentou infecção profunda em 1 dos fios. O método mostrou-se eficiente independente da etiologia com $100 \%$ de consolidação além de permitirem uma certa independência ao paciente durante o tratamento.

\section{SUMMARY}

There had been heated 28 patients in a total of 29 feet, with na age average of 25,8, predominance in the quality of being male 16 patients (57,2\%), white

color 25 patients $(89,2 \%)$, right side 16 patients $(57,2 \%)$. As the ethiology there were a predominancy of the calcaneum fracture's consequence 11 patients (37,9\%) and poliomyelitis 11 patients (6,9\%), bone bar 2 patients (6,9\%), primary arthrosis 02 patients (6,9\%) abd cerebral palsy 1 patient (3,5\%). The average time of consolidation was 3,5 months. There had been used bone graft in 11 patients (44\%). There were the necessity to promote the calcaneum extension to raise the pitch of itself, in 2 cases (6,9\%). The mounting is simple and it relies on 2 rings transbone settlement through 2 strings fixed in the talus and 2 in the calcaneum. As the result was obtained in $100 \%$ of consolidation, pain's absence and osteopethosis and feet's great sensibility. In the complications there were found, besides the usual or method itself 1 (3,5\%) patient. Showed deep infection in 1 of the strings. The method has showed efficient, independent of the ethiology with $100 \%$ of consolidation beyond to permit a certain independancy of the patient during the treatment.

* Trabalho realizado no Departamento de Ortopedia e Traumatologia da Universidade Federal de São Paulo - Escola Paulista de Medicina (Serviço do Prof. Dr. José Laredo Filho).

1 Doutor em Medicina, Professor Adjunto do Departamento de Ortopedia e Traumatologia, Chefe do Grupo de Fixadores Externos da Unifesp Escola Paulista de Medicina.

2 Mestre em Ortopedia e Traumatologia, Assistente do Grupo de Fixadores Externos da Unifesp - Escola Paulista de Medicina.

3 Mestre emOrtopedia e Traumatologia, Assistente do Grupo de Fixadores Externos da Unifesp - Escola Paulista de Medicina.

4 Pós Graduando do Departamento de Ortopedia e Traumatologia, Assistente do Grupo de Fixadores Externos da Unifesp - Escola Paulista de Medicina.

5 Doutor em Medicina, Professor Adjunto do Departamento de Ortopedia e Traumatologia, Chefe do Grupo de Pé da Unifesp - Escola Paulista de Medicina.

6 Colaborador do Grupo de Fixadores Externos da Unifesp - Escola Paulista de Medicina. 


\section{INTRODUÇÃO}

Inúmeros são os métodos existentes para se promover a Artrodese Subtalar do Pé que vai desde procedimentos mais simples como o utilizado pela técnica da trefina (Magalhães e Col.. ${ }^{21}$ até procedimentos mais complexos em que há necessidade de colocação de enxerto e osteossíntese interna.

Os autores mostram uma nova opção de tratamento nos casos em que existe a necessidade da artrodese subtalar ou da artrodese tríplice através da fixação externa, com o desenvolvimento de uma montagem pessoal simplificada, mas que dá grande estabilidade e compressão no foco da artrodese, além de dar grande comodidade ao paciente permitindo que o mesmo deambule com carga no pós-operatório imediato.

\section{MATERIAL E MÉTODO}

A casuística consta de 28 pacientes, com um total de 29 pés tratados no Departamento de Ortopedia e Traumatologia da Universidade Federal de São Paulo - Escola Paulista de Medicina, no período de 1989 a 1997. A idade mínima foi de 15 anos e a máxima de 54 anos com uma média de 25,8 anos. Quanto ao sexo 16 pacientes $(57,2 \%)$ eram masculino e 12 (42,8\%) feminino; a cor branca apresentou 25 pacientes $(89,3 \%$ ) e não branca 03 pacientes $(10,7 \%)$. Quanto ao lado, 16 pés $(55,2 \%)$ eram do direito e 13 $(44,8 \%)$ do esquerdo. O tempo mínimo de tratamento foi de 2,8 meses e o máximo foi de 6,5 meses, com uma média de 3,8 meses. O tempo de seguimento mínimo foi de 1 ano e o máximo de 8 anos com uma média de 4,3 anos. Quanto à etiologia houve predomínio das seqüelas de fraturas do calcâneo em 11 pés (37,9\%), seqüela de poliomielite em 11 pés $(37,9 \%)$ sendo as outras causas necrose do talus em 2 pés (6,9\%), barra óssea 2 pés (6,9\%), artrose primária 2 pés $(6,9 \%)$ e paralisia cerebral 1 pé $(3,5 \%)$.

Todos os pacientes apresentavam dor incapacitante ao apoio e à marcha e algum desvio em varo e valgo do retro pé no pré operatório.

Um dos pacientes com necrose do talus e osteossíntese com parafuso, apresentava concomitantemente infecção (Staphilococus aureus) que atingia a tíbio társica.

A metodologia utilizada foi a idealização de uma montagem simplificada a 2 semi-anéis acoplados à placas de conexão, um fixado no talus com 2 fios olivados cruzados e um semi-anel fixado no calcâneo também com 2 fios olivados.

Quando houve necessidade de se artrodesar a médiotársica (talo-navicular e calcâneo-cubóidea) um $3^{\circ}$ fio era acoplado no

\section{INTRODUCTION}

Countless they are the existent methods to promote Artrodese Subtalar of the Foot that is going from simpler procedures as used him/it by the technique of the trefina (Magalhães and Col. )21 even more complex procedures in than there are need of graft placement and osteossintese it interns.

The authors show a new treatment option in the cases in that the need of the artrodese subtalar exists or of the artrodese triple through the fixation expresses, with the development of a simplified personal assembly, but that gives great stability and compression in the focus of the artrodese, besides giving great comfort to the patient allowing

\section{MATERIAL AND METHOD}

The casuistry consists of 28 patient, with a total of 29 feet treated in the Department of Orthopedics and Traumatologia of the Federal University of São Paulo - School From São Paulo of Medicine, in the period from 1989 to 1997 . The minimum age was of 15 years and the 54 year-old maxim with a 25,8 year-old average. With relationship to the sex 16 patient $(57,2 \%)$ they were masculine and $12(42,8 \%)$ feminine; the white color presented 25 patient $(89,3 \%)$ and not white 03 patient $(10,7 \%)$. With relationship to the side, 16 feet $(55,2 \%)$ they were of the right and $13(44,8 \%)$ of the left. The minimum time of treatment was of 2, 8 months and the maximum was of 6,5 months, with an average of 3,8 months. The time of minimum following was of 1 year and the 8 year-old maximum with a 4,3 year-old average. With relationship to the aetiology there was prevalence of the sequels of fractures of the calcâneo in 11 feet $(37,9 \%)$, poliomyelitis sequel in 11 feet $(37,9 \%)$ being the other causes necrosis of the talus in 2 feet $(6,9 \%)$, it obstructs bony 2 feet $(6,9 \%)$, artrose primary 2 feet $(6,9 \%)$ and paralysis cerebral 1 foot (3,5\%).

All the patients presented pain incapacitante to the support and the march and some deviation in I beat and valgo of the retro foot in the operative pré.

One of the patients with necrosis of the talus and osteossintese with screw, presented concomitantemente infection (Staphilococus aureus) that reached the tíbio társica.

The used methodology was the idealização of an assembly simplified to 2 semi-rings coupled to connection plates, a fastened in the talus with 2 threads crossed olivados and a semi-ring also fastened in the calcâneo with 2 threads olivados. 
sistema em forma arqueada para que houvesse possibilidade de compressão dessas articulações ou as mesmas foram fixados com agrafes de Blount. Nos casos em que não havia uma importante lesão articular, promovia-se a abertura prévia da articulação, com cruentização da mesma e compressão através do fixador.

Em 13 pés (44,8\%) houve a necessidade de utilização de enxerto ósseo, retirado do ilíaco contra lateral, para preenchimento do espaço articular. Em 02 casos (6,9\%) houve a necessidade de se promover o alongamento posterior do calcâneo para se aumentar o pitch do mesmo.

Carga parcial com muletas foi apresentado no P.O imediato e após 2 a 3 semanas, após a retirada dos pontos e ter cedido o processo inflamatório provocado pelo ato cirúrgico carga total foi liberada. Uma orientação fisioterápica foi dada e realizada no pós operatório.
When there was need of if artrodesar the médiotársica (shaftnavicular and calcâneo-cubóidea) a $3^{\circ}$ thread was coupled in the system in arched form so that there was possibility of compression of those articulations or the same ones were fastened with agrafes of Blount. In the cases in that there was not an important lesion to articulate, the previous opening of the articulation was promoted, with cruentização of the same and compression through the fixador.

In 13 feet $(44,8 \%)$ there was the need of use of bony graft, retired of the iliaco against lateral, for completion of the space to articulate. In 02 cases (6,9\%) there was the need to promote the subsequent prolongation of the calcâneo to increase the pitch of the same.

Partial load with crutches was presented in immediate P.O and after 2 to 3 weeks, after the retreat of the points and to have given up the inflammatory process provoked by the act surgical total load it was liberated. An orientation fisioterápica was given and accomplished in the operative powders.

\section{ILLUSTRATIONS}

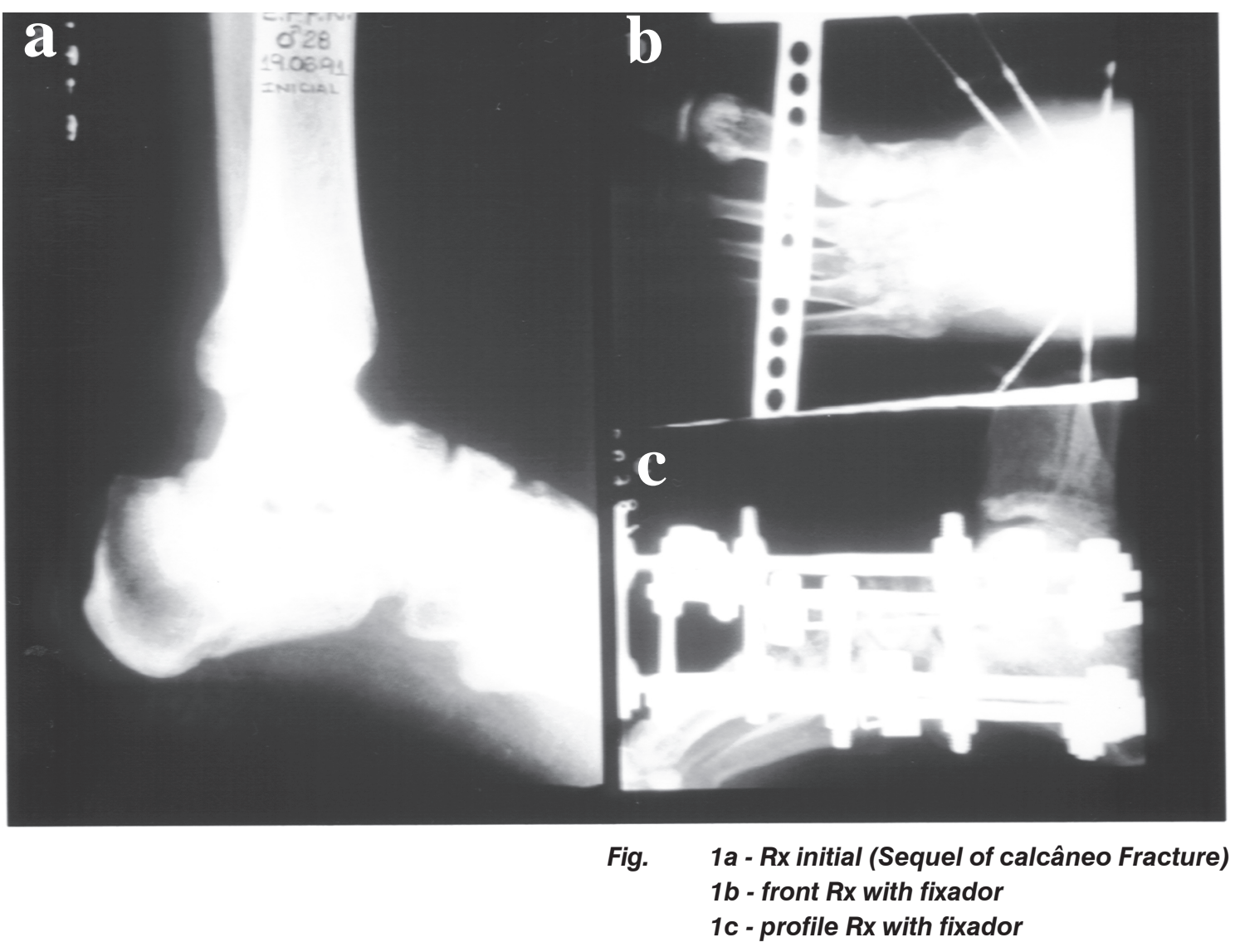




\section{ILLUSTRATIONS}

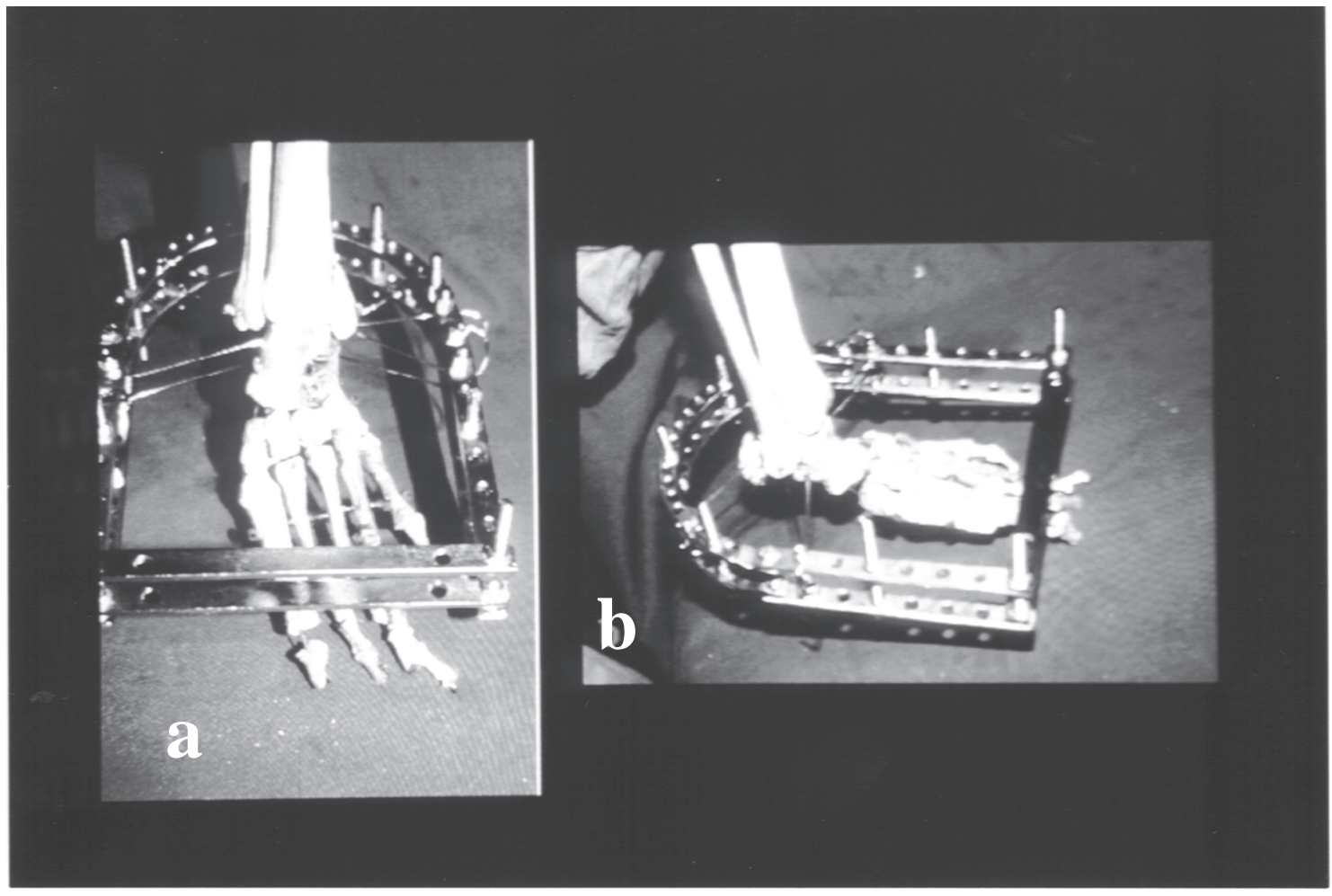

Fig. $\quad 2 a-$ Assembly of seen Fixador of front $2 b$ - Assembly fixador seen lateral

\section{RESULTADOS}

Foi obtido consolidação nos 29 pés (100\%). Em todos os casos houve desaparecimento da dor. Em 24 casos (82,7\%) houve correção total do desvio do retro pé sendo que em 3 pés $(10,3 \%)$ permaneceu desvio , 2 em varo e 1 em valgo que não ultrapassou $5^{\circ}$ e 1 paciente permaneceu com varo menor que $5^{\circ}$.

O caso que apresentou necrose do talus, curou após artrodese da tíbio-társica.

\section{RESULTS}

It was obtained consolidation in the 29 feet (100\%). In all the cases there was disappearance of the pain. In 24 cases (82,7\%) there was total correction of the deviation of the retro foot and in 3 feet (10,3\%) deviation stayed, 2 in I beat and 1 in valgo that didn't surpass $5^{\circ}$ and 1 patient stayed with I beat smaller than $5^{\circ}$. The case that presented necrosis of the talus, cured after artrodese of the tíbio-társica. 


\section{COMPLICAÇÕES}

Além das complicações menores comuns ao método como a dor, edema, infecção superficial, um dos pacientes apresentou infecção profunda em um dos fios havendo necessidade da troca do mesmo com cura do processo.

A paciente que apresentava necrose do talus com osteossíntese por parafuso (seqüela de fratura-luxação) apresentou regressão do quadro após a retirada do material de síntese, houve reagudização do processo durante o período de evolução havendo necessidade de se promover a artrodese da tíbio társica com cura total do processo infeccioso.

\section{COMPLICATIONS}

Besides the smaller complications common to the method as the pain, edema, superficial infection, one of the patients presented deep infection in one of the threads having need of the change of the same with cure of the process.

The patient that presented necrosis of the talus with osteossintese for screw (fracture-dislocation sequel) it presented regression of the picture after the retreat of the synthesis material, there was reagudização of the process during the evolution period having need to promote the artrodese of the tíbio társica with total cure of the infectious process.

\section{ILLUSTRATIONS}

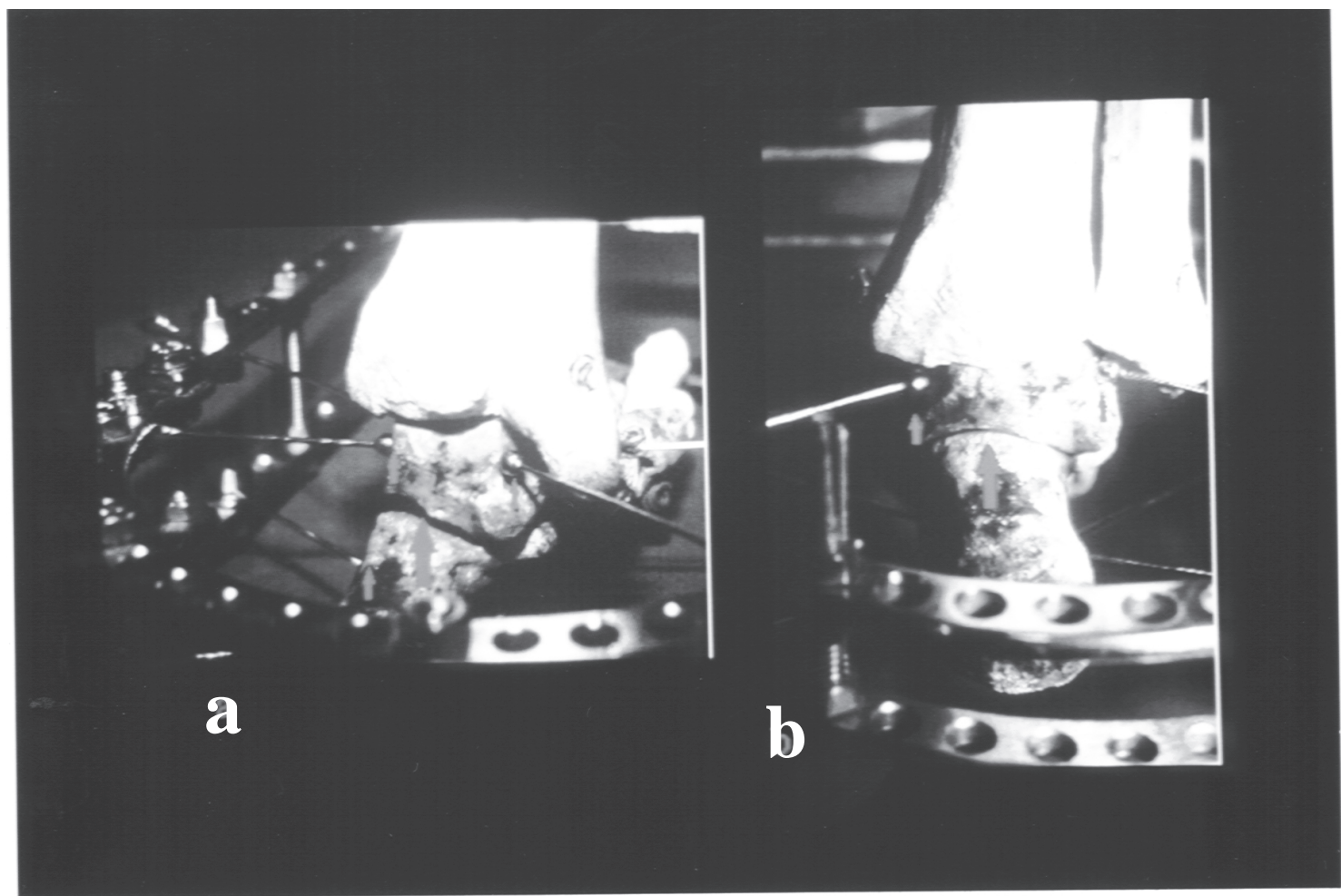

Fig $\quad 3 a$ - Seen subsequent assembly fixador. Larger arrow shows sub-talar open before the compression. Arrow minor shows threads olivados.

$3 b$ - Seen subsequent assembly of the fixador. Smaller arrow shows sub-talar closed after compression enter the rings. Smaller arrows show threads olivados. 


\section{ILLUSTRATIONS}

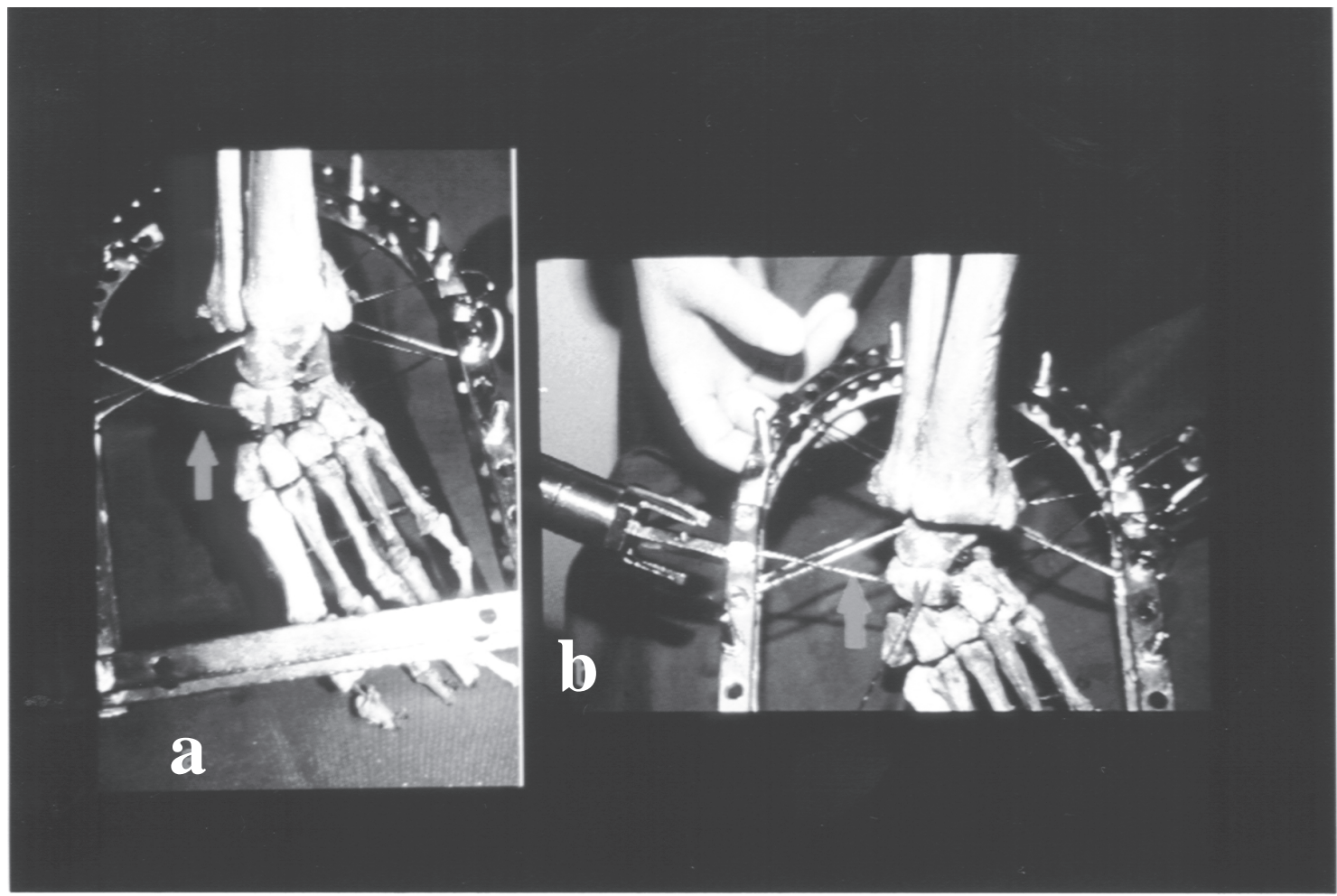

Fig. $\quad 4 a-$ Seen previous it shows passage of the $3^{\circ}$ thread in the navicular and cubóide. Arrow shows shaftnavicular open before the positioning of the thread. $4 \mathrm{~b}$ - Seen previous showing the tencionamento of the $3^{\circ}$ thread. Arrow showing closing of the shaftnavicular and calcâneo-cubóidea.

\section{RESULTADOS}

- Houve consolidação em 100\% das artrodeses.

- Desaparecimento da dor incapacitente em todos os casos.

- Correção de deformidade do retro pé em 82,7\% sendo que em 10,3\% dos casos, as deformidades que permaneceram não eram de fundamental importância.

\section{RESULTS}

- There was consolidation in $100 \%$ of the artrodeses.

- Disappearance of the pain incapacitente in all the cases.

- Correction of deformity of the retro foot in $82,7 \%$ and in 10,3\% of the cases, the deformities that stayed they were not of fundamental importance. 


\section{CONCLUSÕES}

O método mostrou-se eficiente independentemente da etiologia com $100 \%$ da consolidação, desaparecimento do sintoma doloroso e correções das deformidades além de dar opção nos casos em que há um grande afundamento do calcâneo com elevação da tuberosidade posterior do mesmo de se promover o abaixamento com alongamento posterior e para baixo, aumentandose dessa maneira o pitch do calcâneo.

Pela simplicidade da montagem possibilita um conforto ao paciente no pós operatório imediato permitindo carga total precocemente.

\section{CONCLUSIONS}

The method was shown efficient independently of the aetiology with $100 \%$ of the consolidation, disappearance of the painful symptom and corrections of the deformities besides giving option in the cases in that there is a great sinking of the calcâneo with elevation of the subsequent tuberosidade of the same of promoting the abaixamento with subsequent prolongation and down, increasing of that sorts out the pitch of the calcâneo.

For the simplicity of the assembly it makes possible a comfort to the patient in the immediate operative powders allowing load total precocemente.

\section{ILLUSTRATIONS}

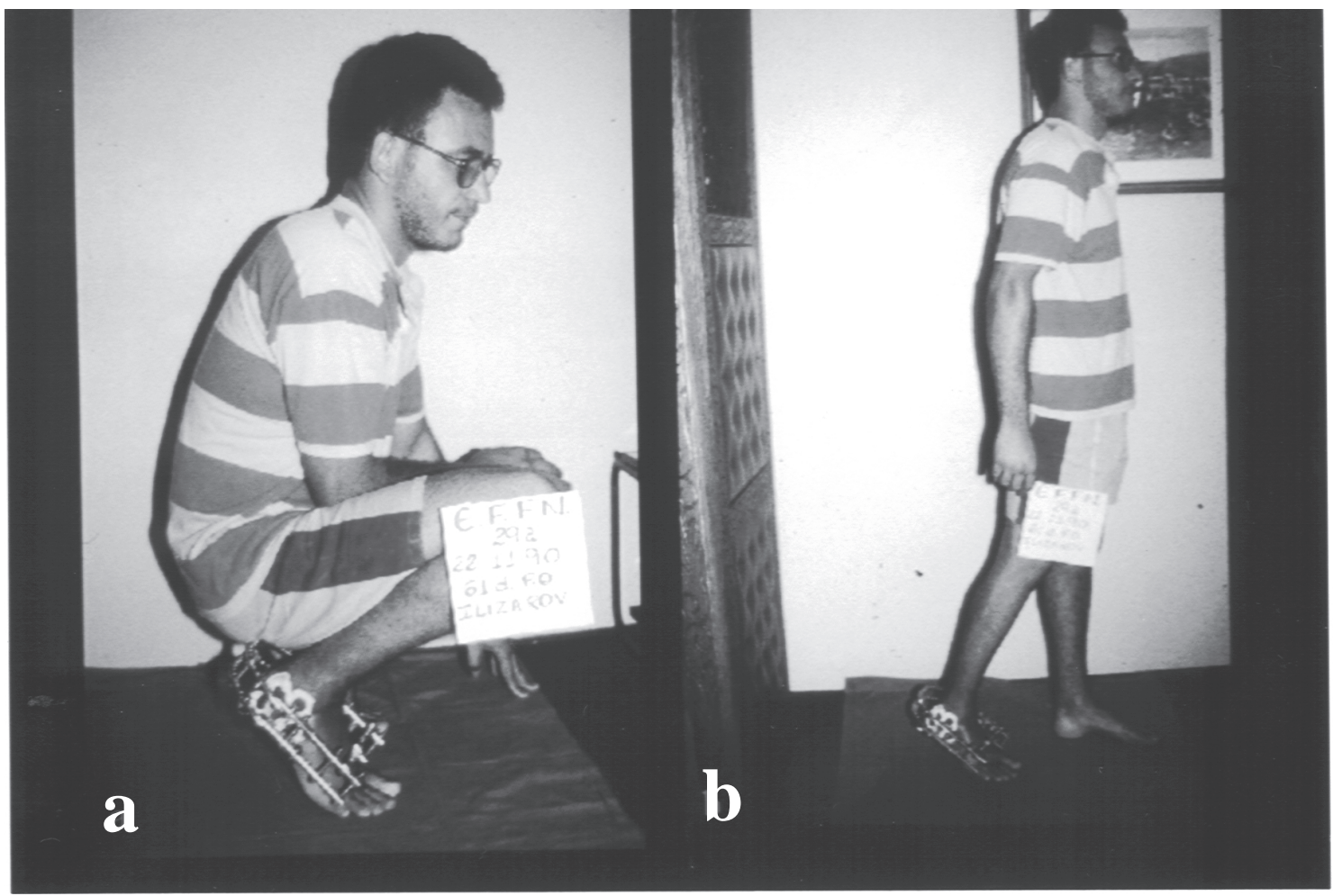

Fig. $\quad 5 a, 5 b$ - Patient during treatment. Stooping and in foot with total load. 


\section{ILLUSTRATIONS}

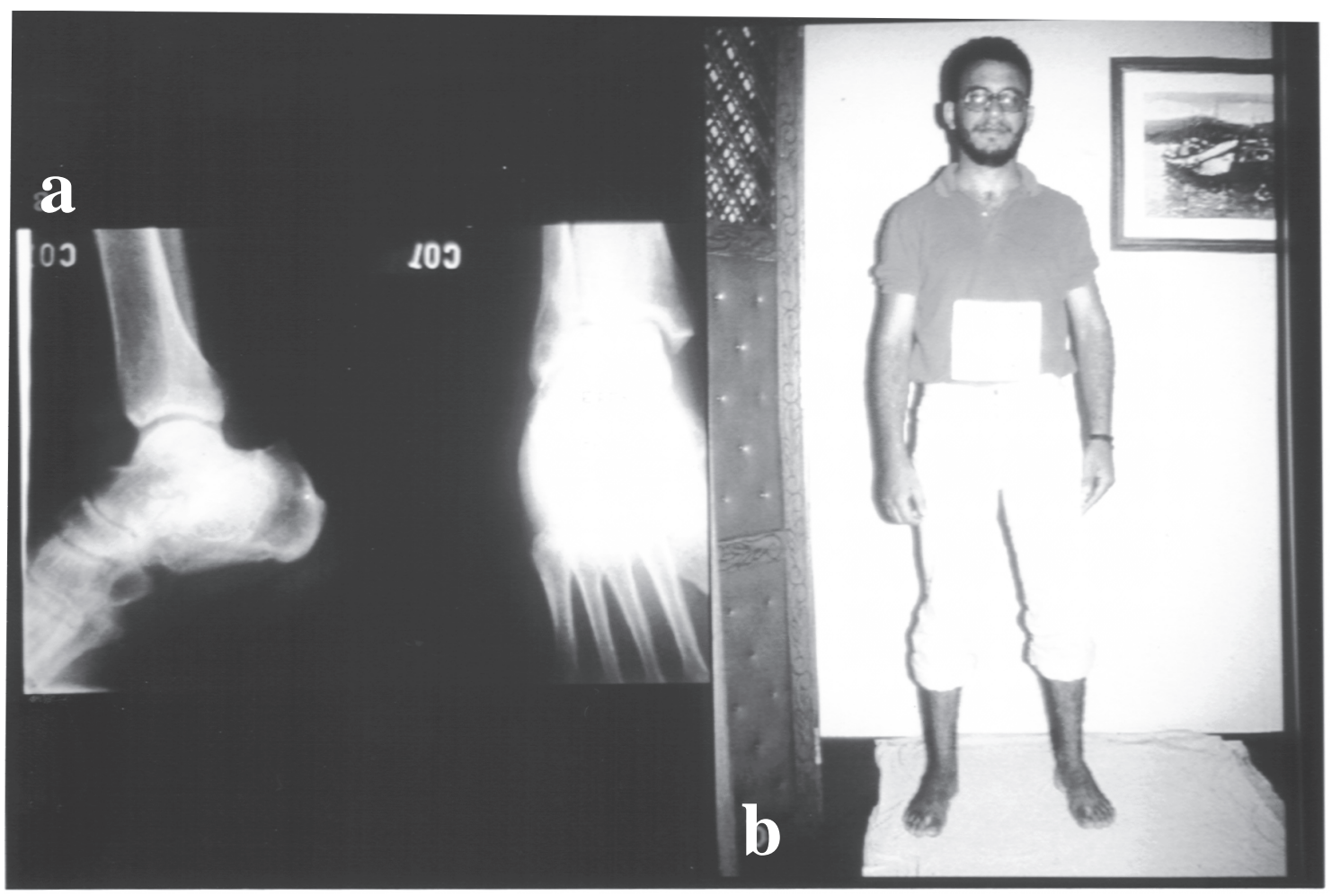

Fig. $\quad 6 a-f i n a l ~ R x$ without the fixador. Artrodese consolidated subtalar. $6 b$ - final Patient.

\section{REFERÊNCIAS}

1. ASAMI GROUP - Joint Contractures. Operative Principles of llizarov. Ed. Medi Surgical Vídeo. Cap. 33: 436-440, 1991.

2. ALBEE, F. H. - Orthopedic and Reconstruction Surgery, Industrial and Civilian, Philadelphia - London, Saunders, 1917 appud SOREN, A Safe inlay of bone graft in arthrodesis. Clin. Orthop.58: 147 - 152, 1968.

3. BATALHA, E.S.C. - New method of intra-articular arthrodesis by transposition of local cancellous bone. A preliminary report. Am.J. Surg., 85-92, 1950.

4. BIANCHI-MAIOCCHI, A; BENEDETTI,G.B.; CATAGNI, M.A;CATTANEO,R.; TENTORI,L.; VILLA, A; L'osteossintese Transsosea Secondo G.A llizarov. Aspetti Clinici Dell'impiego Dell' apparato di Compressione-Distrazione di G.A Ilizarov in Traumatologia. Ed. Medi Surgical Video, Milano - Itália. Cap.2, pag. 157-77, 1983.
5. BLAIR, H.C. - Comminute fractures and fracture dislocations of the body of the astragalus. Operative treatment. Am.J.Surg., 59:3743, 1943.

6. CAMPBELL, P. - Arthrodesis of the ankle with modified distractioncompressiom and bone grafting. J. Bone Joint surg., 72-A:551556,1990

7. CANTALAMESSA, C. - Arthrodesi della tíbio-társica per esiti di fratture del collo piede. Revisione della casística e controllo a distanza. Clin. Orthop., 268: 49-55, 1991.

8. CATAGNI, M.A.; Fratture e Pseudoartrosi - Trattamento con fissatore esterno circolare di llizarov; Studio CA, 1997.

9. CATAGNI, M.A.; MALZEV, V.; KIRIENKO, A.; Advances in llizarov Apparatus Assembly - Fracture treatment Pseudoarthroses - 


\section{ILLUSTRATIONS}

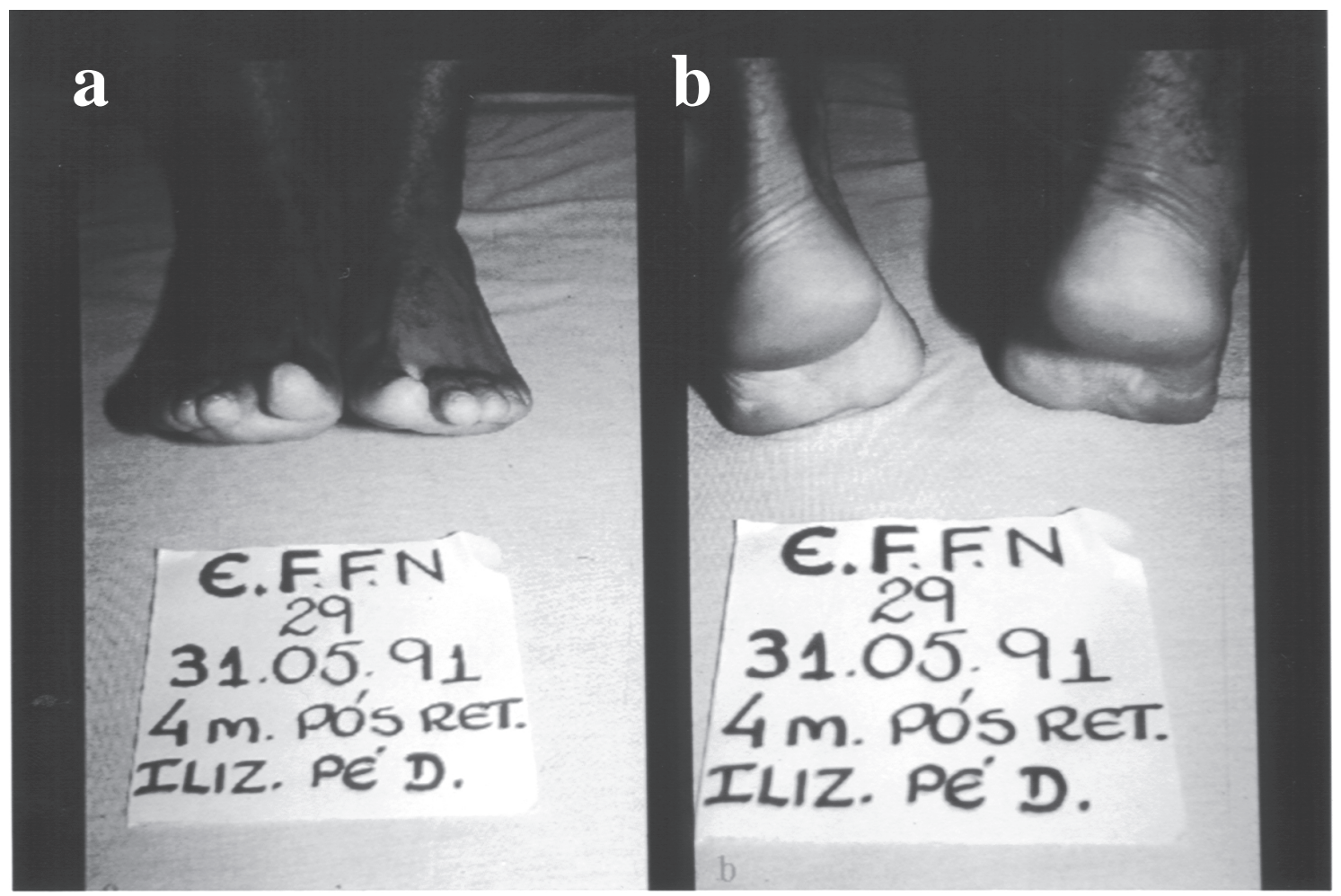

Fig. $\quad 7 a$ - final Picture of the patient's foot.

$7 \mathrm{~b}$ - final Picture of the foot seen for behind.

Lengthening Deformity Correction; Ed. A. Bianchi-Maiochi, 155p., 1997.

10. DENNIS, D.A; CLAYTON, M.L.; WONG, D.A; MACK, R.P.; SUSMAN, M.H. - Internal fixation compression arthrodesis of the ankle. Clin. Orthop., 253: 212-220, 1990

11. FONTANILLS, C.F.; LOPEZ, A; ROQUE, D.F.; CAMPOS, F.R. Artrodesis de tobillo por compresion externa. Rer. Cuba.Ortop. Traumatol., 1: 17-21, 1987

12. GOLYAKHOVSKY, V.: Dobradiças. Manual de Técnicas Operatórias do Método de llizarov, 6: 123-130, 1996.

13. GOLYAKHOVSKY, V.: Correção das contraturas articulares. Manual de Técnicas Operatórias do Método de Ilizarov, 6: 130139, 1996.
14. GRUEN, G.S. \& MEARS, D.C. - Arthrodesis of the ankle and subtalar joints, Clin. Orthop., 268: 15-20, 1991.

15. HAWKINS, B.J.; LANGERMAN, R.J., ANGER, D.M.; CALHOUN, J.H. - The llizarov technique in ankle fusion. Clin. Orthop., 303: $217-225,1994$.

16. ILIZAROV, G.A. - The Apparatus: Components and Biomechanical Principles of Aplication. Transosseus Osteosynthesis. Ed. Springer - Verlag, 329-68, 1992.

17. JAHSS, M. - Disorders of the foot \& ankle, 2 ed. Toronto, W.B. Saunders Company, 1991,

18. JOHNSON, J.E. \& JOHNSON, K.A - Dowel arthrodesis for degenerative arthrites of the tarsometatarsal (Lisfranc) joints. Foot \& Ankle int., 6: 243-253, 1986. 
19. JOHNSON, K.A - Arthrodesis of the foot and ankle. In: Surgery of the foot and ankle. New York, Raven Press, 1989, v.6, p. 151208.

JOHNSON, E.E.; WELTMER, J.; LIAN, G.J.; CRACCHIOLLO, III, A llizarov ankle arthrodesis. Clin. Orthop., 280: 160-169 , 1992.

21. MAGALHÃES, A C. - Artrodese do Tornozelo pelo Método das Trefinas: Estudo de 30 Pacientes. Tese apresentada à Universidade Federal de São Paulo - Escola Paulista de Medicina para obtenção do Título de Doutor em Medicina, São Paulo, 1995.

22. MEAD, N.C. - Fusion of the ankle joint. A description of a simple, effective surgical technic. Clin. Orthop., 23: 211-15, 1953.

23. MOECKEL, B.H.; PATTERSON, B.M.; INGLIS, A E.; SCULCO, T.P. - Ankle Arthrodesis. A comparison of internal and external fixation. Clin. Orthop., 268: 78-83, 1991.

24. MYERSON, M.S. \& QUILL, G. - Ankle arthrodesis. A compariosn of na arthroscopic and na open method of treatment. Clin. Orthop., 268: 84-95, 1991

25. NERY, C.A S.; BRUSCHINI, S.; MAGALHÃES, A A C.; SODRÉ, H.; ,IZUSAKI, J.M. - Uso de trefinas: Um método simples e útil para artrodeses do tornozelo e pé. Rer. Bras. Ortop. 27: 157 - 161, 1992.

26. PAPA, J. \& GIRARD, P. - Salvage, with arthrodesis, in intractable diabetic neuropathic arthropathy of the foot and ankle J. Bone Joint Surg., 75-A: 1056-1066, 1993.

27. PETERSON, H.A - Dowel graft technique for triple arthrodesis in talocalcaneal coalition - report of a case with 12-year follow-up. Foot \& Ankle int. vol (9).: 201-203, 1989

28 REAGNAULD, B. The foot. Pathology, aetiology, semiology, clinical investigation and therapy. Berlim, Springer-Verlag, 1986.

29. SHEVTSOV, V.I. (et al) : Osteossíntese Transóssea pelo Método do Centro de Reabilitação Ortopédica do Acadêmico Gavriil Abramovich Ilizarov. Defeitos Ósseos de Membros Inferiores, 287-301, 1996.

30. STAPLE, S.O - Posterior arthrodesis of the ankle and subtalar joint. J. Bone Joint Surg., 38-A: 50, 1956.

31. STEWART, M. - Arthrodesis. In: Campbell 's Operative Orthopaedics. 6 ed., St. Louis, C.V. Mosby Company, 1980. 